\title{
Oil extraction from olive foot cake with acidic hexane.
}

\author{
By S. Kmieciak, S. Meziane, H. Kadi and R. Moussaoui. \\ Laboratoire de Revalorisation des sous-produits oléicoles. Unité de Recherche Biologie. Université \\ de TIZI-OUZOU 15000 ALGERIE.
}

\section{RESUMEN}

Extracción de aceite de orujo de aceituna con hexano ácido.

El uso de hexano ácido como disolvente aumenta el rendimiento de aceite extraido de orujo de aceituna.

Se han estudiado dos procedimientos de extracción: extracción al aire libre a temperatura ambiente y extracción exhaustiva en Soxhlet.

En el caso de extracción al aire libre el rendimiento adicional es alrededor del $5 \%$ para un contenido del 2 '5\% en ácido acético y llega a ser en el procedimiento en Soxhlet del $9 \%$ para un contenido en ácido acético del $7{ }^{\prime} 5 \%$. Un análisis del aceite extraido mostró un ligero aumento de la acidez del aceite. La mejora del rendimiento puede ser atribuida a la acción del ácido acético sobre la descomposición de estructuras intercelulares y uniones de lípidos polares. Se ha encontrado que el contenido en fosfolípidos del aceite extraído con el 7'5\% de hexano ácido es 25 veces mayor que con hexano puro.

PALABRAS-CLAVE: Extracción con disolvente - Hexano ácido Orujo de aceituna (extracción).

\section{SUMMARY}

Oil extraction from olive foot cake with acidic hexane.

The use of acidic hexane as a solvent increases the extracted oil yield from olive foot cake.

Two extraction procedures are studied: open air extraction at room temperature and Soxhlet exhaustive extraction.

The additional yield is about $5 \%$ for a $2.5 \%$ acetic acid content in case of open air extraction and turns out to be $9 \%$ for $7.5 \%$ acetic acid content in the Soxhlet pocedure. An analysis of the extracted oil shows a light increase of the acidity of oil. The improved yield may be attribued to the action of acetic acid on the decomposition of intercellular structures and binding of some polar lipids. The phospholipids content of oil extracted with $7.5 \%$ acidic hexane is found to be 25 times more than with pure hexane.

KEY-WORDS: Acidic hexane - Olive foot cake (extraction) - Solvent extraction.

\section{INTRODUCTION}

Olive foot cake contains remarkable percentage of residual oil which can be recovered by solvent extraction mostly with aid of hexane.

Hensarling (1) (2) has shown that an addition of acetic acid to hexane increases the yield of the extracted oil from some fatty materials such as soybean and cottonseed.

In this paper, we study the effect of acetic acid presence in hexane on the quantity and quality of extracted oil from olive foot cake.

\section{EXPERIMENTAL}

\subsection{Material}

A sample of olive foot cake was taken from an oil mill equipped with a hydraulic press and a centrifuge. The initial moisture content of the sample was $27.8 \%$, which was reduced to $6.9 \%$ by drying at $80^{\circ} \mathrm{C}$. This was done to avoid deterioration of the cake and to have an optimum moisture content for extraction. The olives are from the Chemlal variety.

\subsection{Extraction}

Two extraction methods have been used:

- extraction in an open air reactor at room temperature.

- exhaustive extraction in the Soxhlet apparatus.

\subsubsection{Extraction in an open air reactor.}

A preliminary study was done to determine the optimum conditions for extraction using pure hexane as solvent. Following parameters are studied:

- ratio of solvent volume to the mass of olive foot cake: L/S $\left(\mathrm{cm}^{3} / \mathrm{g}\right)$.

-contact time: $\tau$ ( $\mathrm{min})$

-siirring rate: $N$ (rotation $/ \mathrm{min}$ )

The optimum values are found to be:

$L / S=3 \mathrm{~cm}^{3} / \mathrm{g} ; \tau=5 \mathrm{~min} ; \mathrm{N}=300 \mathrm{rot} / \mathrm{min}$.

A becher of $500 \mathrm{ml}$ has been used as a reactor.

In order to study the effect of acetic acid content in hexane on the oil yield, we carried out five series of experiments by varying acetic acid percentage as: $0 ; 2.5 ; 5.0 ; 7.5$ and $10.0 \%$. Each serie was repeated four times. The weight of cake was $50 \mathrm{~g}$.

The separation of solids from resultant miscella was performed by filtration in a Buchner funnel using a paper filter of medium porosity (Ederol N.3). The filtration was carried out under reduced pressure and the same conditions were used for all experiments. 
None of the filter aids was used and no cake washing was resorted to.

The miscella was distilled by means of a rotary evaporator. The last traces of acetic acid were removed from the extracted lipids in a oven at $103^{\circ} \mathrm{C}\left( \pm 2^{\circ} \mathrm{C}\right)$ until there was no acetic odor.

\subsubsection{Exhaustive extraction}

The exhaustive extraction was carried out in a Soxhlet apparatus using the general rules for determining oil content in fatty raw materials and products. The weight of cake was $20.0 \mathrm{~g}$; the volume of the flask was $250 \mathrm{ml}$ and the sand bath was used for heating. After 6 hours, the extraction was interrupted and the content of the thimble was ground in a mortar.
The extraction was continued until a constant weight of the extracted oil was obtained (nearly 12 hours).

\section{RESULTS AND DISCUSSION}

\subsection{Extraction yield}

\subsubsection{Open air extraction}

The results obtained by extraction in an open air reactor are given in Table $\mathrm{I}$. We note that:

- the addition of acetic acid has a positive effect on the extraction yield.

- no further significant improvement in yield is observed for acetic acid content of over $2.5 \%$.

- at $2.5 \%$ of acetic acid content, we obtain $5 \%$ more of lipids as compared to pure hexane.

Table 1

Open air extraction under standard conditions.

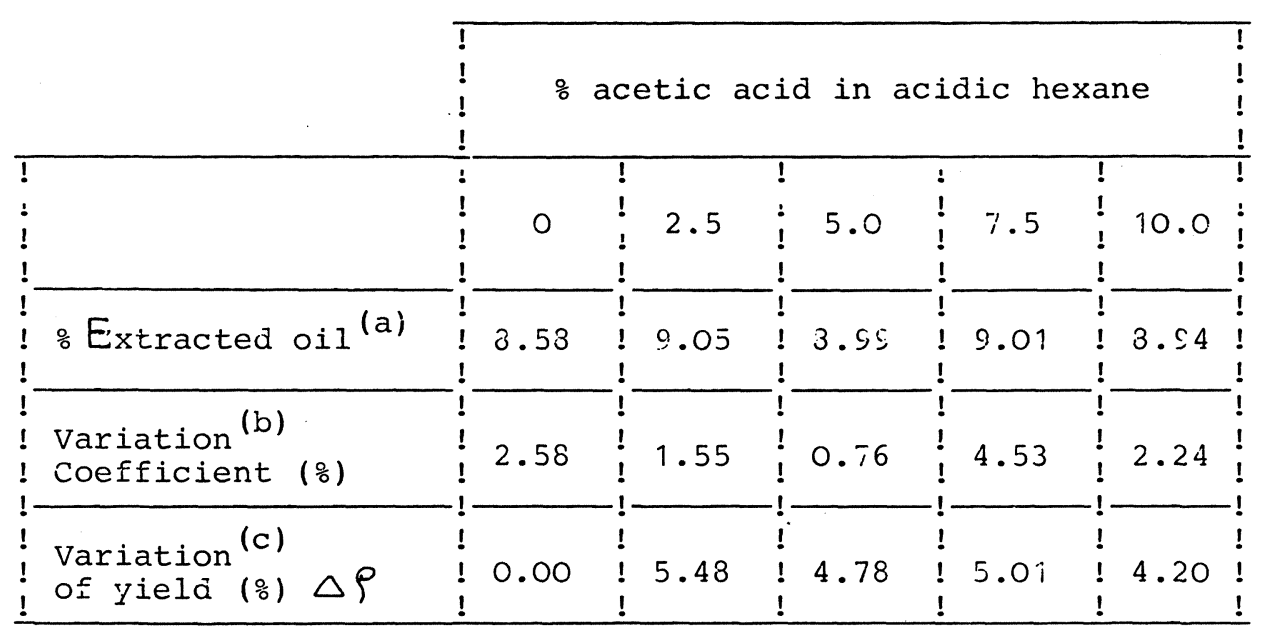

(a) on dry basis

(b) number of experiments $=4$

(c) $\Delta P=\frac{\mathrm{m}_{\mathrm{S}}-\mathrm{m}_{\mathrm{H}}}{\mathrm{m}_{\mathrm{H}}} \cdot 100 \%$

Where: $\mathrm{m}_{\mathrm{S}}=$ mass of oil extracted with acidic hexane

$\mathrm{m}_{\mathrm{H}}=$ mass of oil extracted with pure hexane.

\subsubsection{Soxhlet extraction.}

The results obtained are shown in Table II. The role of acetic acid on lipids removal is more significant in this case. The maximum yield is obtained for $7.5 \%$ of acetic acid content in solvent and corresponds to $9 \%$ more of lipids as compared to pure hexane extraction.

\subsection{Extracted oil analysis}

\subsubsection{Organoleptic test.}

At $20^{\circ} \mathrm{C}$, the oil extracted with acidic hexane is less clear. A white sediment is observed which increases with acetic acid content. At the same time the colour changes from light yellow to greenish yellow. No undesired changes in odor were observed. 
Table II

Soxhlet exhaustive extraction.

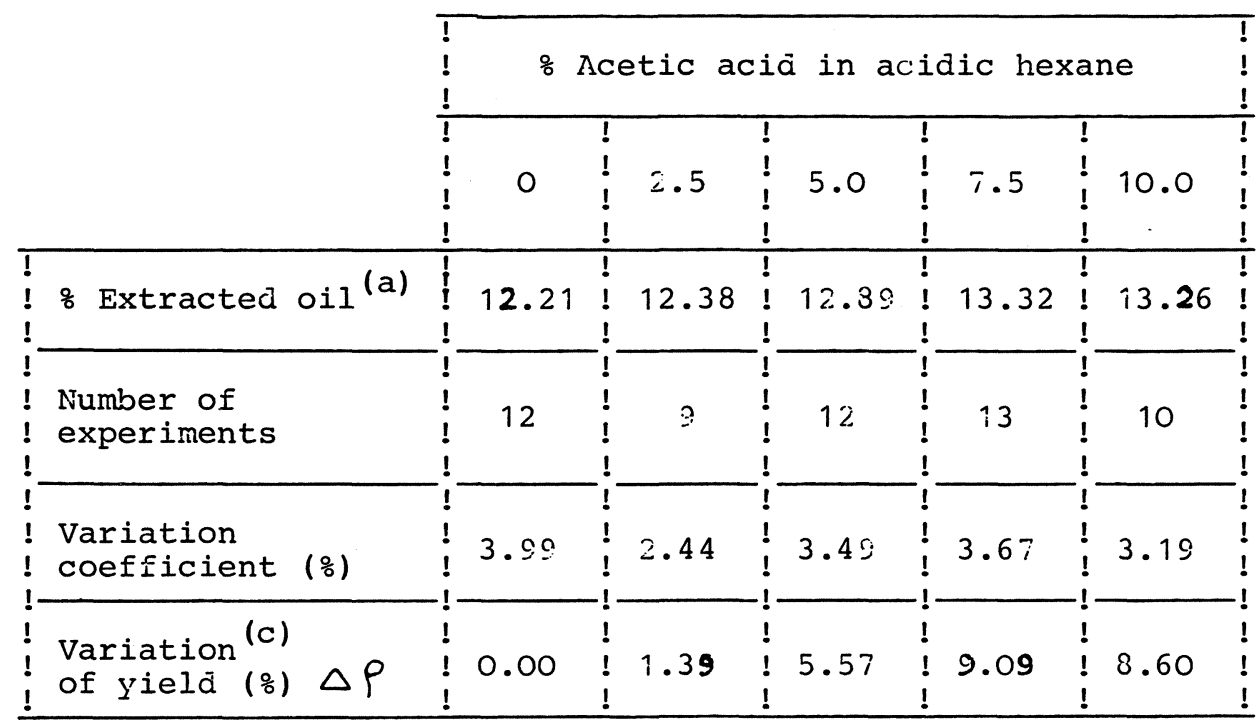

a,c - See Table I.

\subsubsection{Chemical tests}

\section{- Acidity}

As it is shown in Fig. 1, the acidity of extracted oil increases with the acetic acid content in solvent.

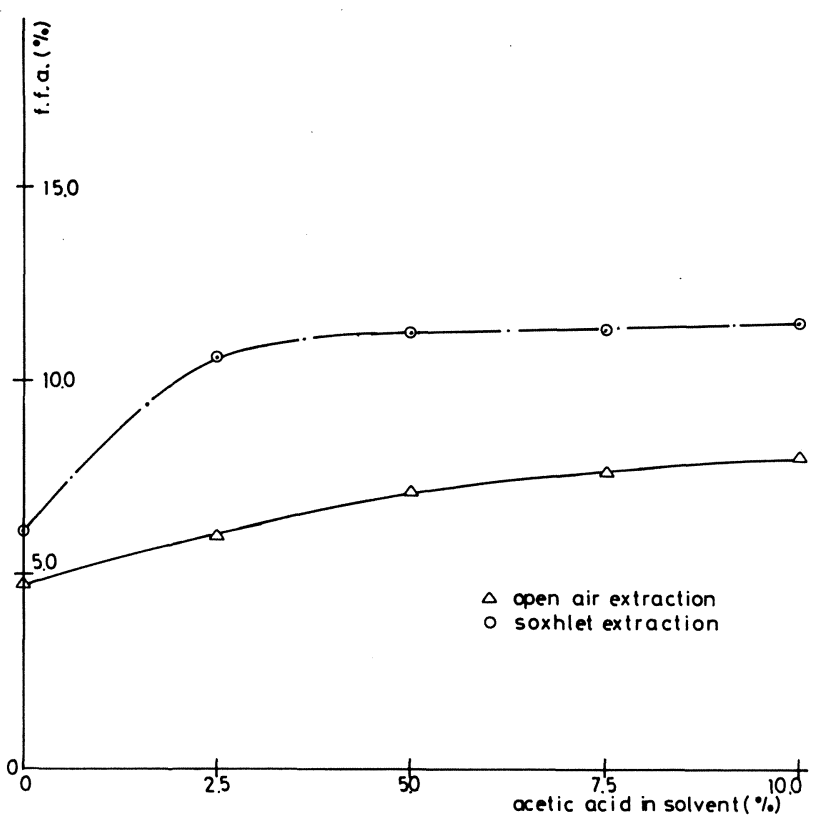

Figure 1

Variation of free fatty acids content of extracted oil as a function of acetic acid content in solvent.
In case of open air extraction, the acidity is practically proportional to the acetic acid content in solvent. At $2.5 \%$ of acetic acid content (which corresponds to maximum yield), the acidity increases by nearly $1 \%$. This increase seems to be tolerable for subsequent utilisation of the oil.

On the other hand, in case of Soxhlet extraction, the acidity increases from $6 \%$ to $11 \%$ as the acetic acid content in solvent attains $2.5 \%$. Beyond this content, the increase in acidity is not significant.

This difference is due to a longer time contact and higher temperature in Soxhlet extraction as compared to the open air extraction.

-Unsaponifiable substances.

The analysis of unsaponifiable substances was carried out for oil extracted by Soxhlet procedure. The results obtained are given in Table III. We notice only a light increase in unsaponifiable substances as compared to extraction with pure hexane. This indicates that the additional amount of oil obtained by acidic hexane is composed of saponifiable matter which can be useful if the oil is used in a soap industry.

- Phospholipids

The analysis of phospholipids (Px26) was also done for oil extracted by Soxhlet procedure. The results are given in Table IV. Phosphorus content was determined spectrophotometrically in presence of ammonium vanadate (3).

Contrary to only a slight increase of unsaponifiable substances, the phospholipids vary considerably with acetic acid content in solvent. The maximum value is found to be 25 times bigger than that obtained with pure hexane. 
Table III

Unsaponifiable substances of oil extracted with acidic hexane.

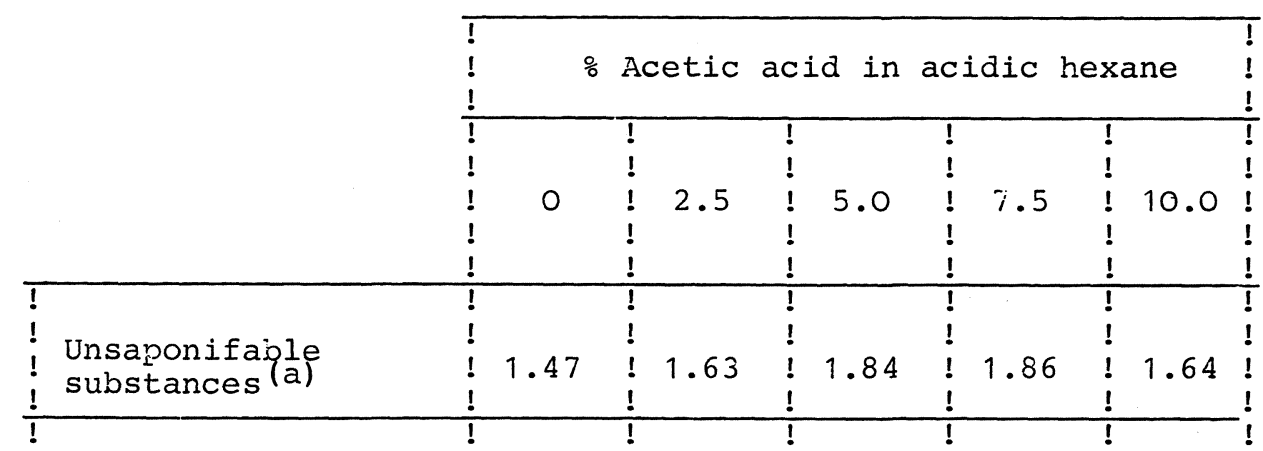

(a) - mean value of three experiments.

Fig. 2 show a similar variation pattern for phospholipids and oil yield with acetic acid content in solvent. This behaviour is further confirmed in Fig. 3 which show a linear correlation between the oil yield

Table IV

Variation of phospholipids content as a fonction of acetic acid content in solvent.

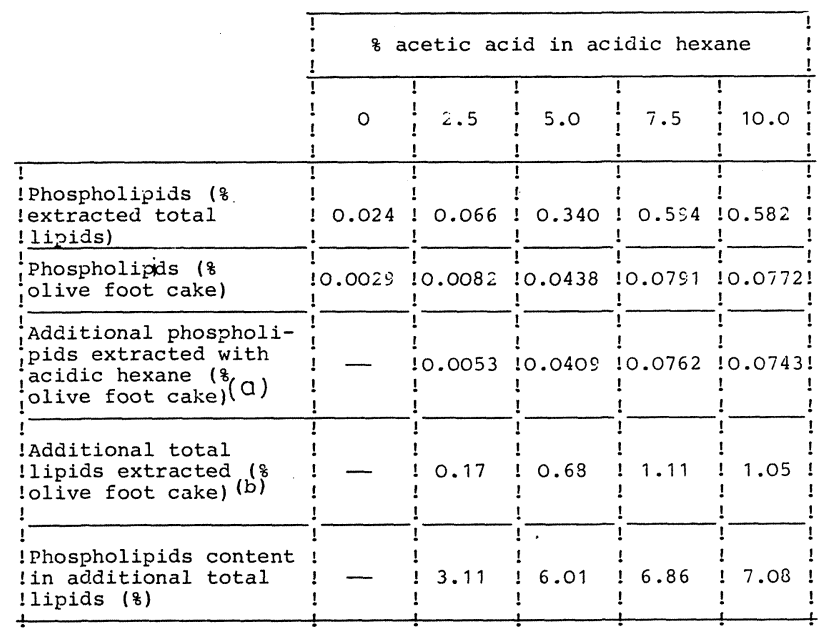

(a) - difference between the phospholipids content in oil extracted with acidic hexane and that extracted with pure hexane.

(b) - difference between total lipids extracted with aciaic hexane and that extracted with pure hexane (See Table II).

The additional oil extracted with acidic hexane originates from the intercellular membrane structures which undergo decomposition in the presence of acetic acid (2). These lipids which are rich in polar components (such as phospholipids, glucolipids) are bound to protein molecules and are freed under the action of acetic acid. In addition, it seems that acetic acid reacts chemically with the organic base of phospholipids which also explains the higher oil yield. From the calculated values presented in Table IV, we can further notice that the additional oil is rich in phospholipids to the tune of $7 \%$. This is in agreement with the earlier observations on high phospholipids contents in membrane lipids (4).

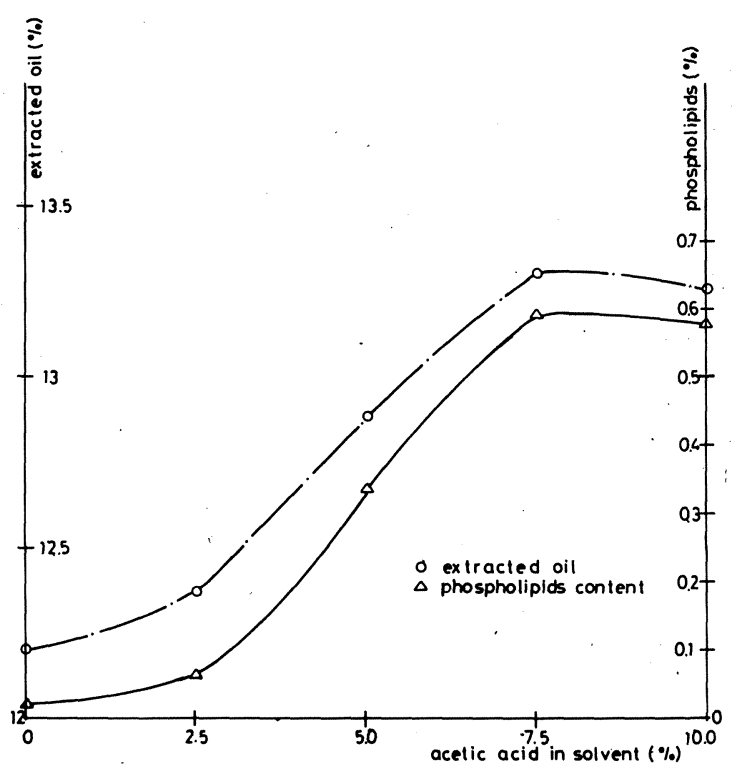

Figure 2

Oil yield and phospholipids content as a function of acetic acid content in solvent.

\section{CONCLUSION}

The study presented here shows that the addition of a little acetic to hexane improves the oil yield from olive foot cake. This increased yield can be useful in olive oil industry. The extracted oil has a slight higher acidity. This oil is richer in phospholipids (25 times) which may be of interest to producers of lecithin as it is a by product of oil refineries.

A technico- economic study is recommended. 


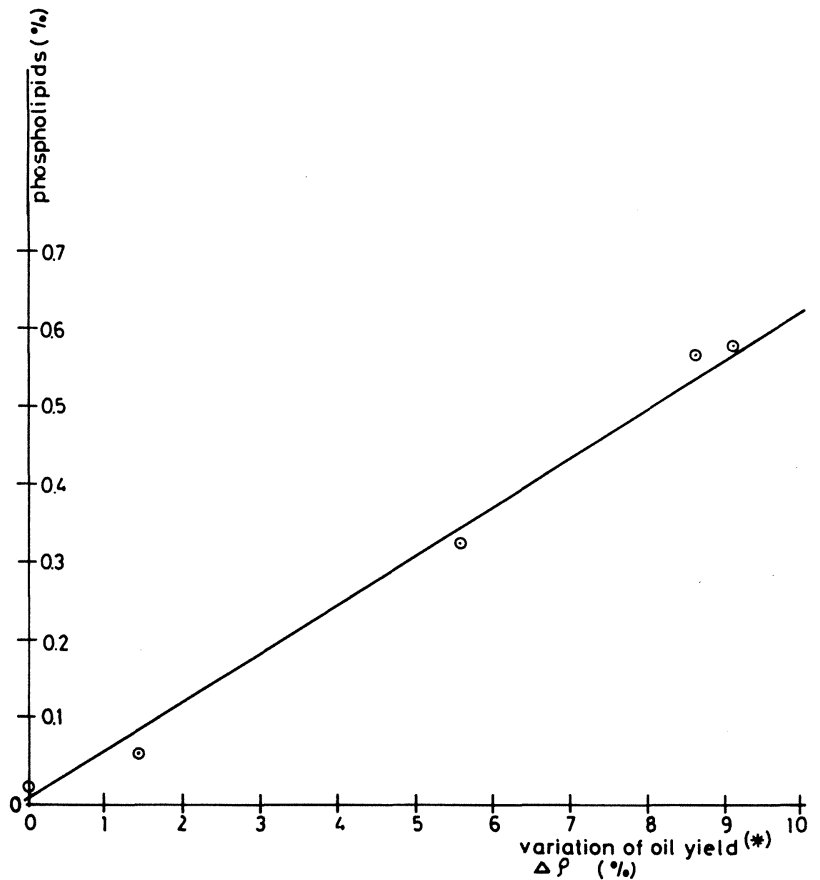

Figure 3

Correlation between extrated oil yield and its phospholipids content.

(*) as compared to pure hexane extraction yield.

\section{BIBLIOGRAPHY}

1. Hensarling, T. P.; Jacks, T. J.- "Acidic Hexane Extraction of Oilseeds: Product Quality".- J. Am. Oil Chemists' Soc. 59 (1982) 516-518.

2. Hensarling, T. P.; Jacks, T. J.- "Solvent Extraction of Lipids from Soybeans with Acidic Hexane".- J. Am. Oil Chemists' Soc. 60 (1983) 783-784

3. Norme Française Homologuée NFT 60-227 - Dosage colorimé trique du phosphore - Méthode Vanadomolybdique.

4. Mazliak, P.- Le métabolisme des lipides dans les plantes supérieures.- Manson el $\mathrm{C}^{\prime \prime}$. ., Paris, 1968.

(Recibido: Mayo 1990) 